\title{
Portveneembolisering før kirurgi av leversvulster
}

\author{
Sammendrag \\ Bakgrunn. Radikal reseksjon er den \\ eneste mulighet for kurativ behandling \\ av maligne leversvulster. En viktig kon- \\ traindikasjon for kirurgi er utilstrekke- \\ lig restlever. Embolisering av portvene- \\ grenen til den affiserte side av leveren \\ kan indusere vekst av den friske delen \\ og dermed gjøre planlagt leverresek- \\ sjon mulig.
}

Materiale og metode. I tidsrommet 2002-06 ble det gjort portveneembolisering hos 18 pasienter $\mathrm{i}$ alderen 35-71 år. Emboliseringen ble utført som intervensjonsradiologisk prosedyre med perkutan transhepatisk teknikk.

Resultater. Den planlagte restleveren $\varnothing k$ te hos alle pasientene med median $45 \%$ (spredning 9-100\%). Leverreseksjon kunne gjøres hos ti. Tumorprogrediering utelukket reseksjon hos sju pasienter, mens én ikke kunne opereres grunnet alvorlig bivirkning av cytostatika. Fireårsoverlevelsen etter kirurgisk reseksjon lå på $58 \%$. Pasienter som ikke kunne leverreseres hadde en median overlevelse på 15 måneder.

Fortolkning. Portveneembolisering fører til en betydelig økning av levervolumet $\mathrm{i}$ ikke-embolisert lever. Teknikken er effektiv for å øke antall pasienter som kan tilbys leverreseksjon. Det er mulig å oppnå en langtidsoverlevelse på linje med overlevelsen hos pasienter som primært er bedømt som operable. Anvendelse av teknikken forutsetter meget god bildediagnostikk for å skille ut dem som sannsynligvis ikke kan profittere på den.

\section{Øystein Mathisen}

oystein.mathisen@rikshospitalet.no Kirurgisk klinikk

\section{Eric Dorenberg}

Bilde- og intervensjonsklinikken

Rikshospitalet

0027 Oslo

\section{Bjørn Edwin}

Kirurgisk klinikk

Rikshospitalet

og

Intervensjonssenteret

\section{Ivar Gladhaug}

Kirurgisk klinikk

Rikshospitalet

og

Fakultetsdivisjonen Rikshospitalet Universitetet i Oslo

\section{Geir Hafsahl}

Bilde- og intervensjonsklinikken Rikshospitalet

\section{Ola Røkke}

Kirurgisk avdeling

Akershus universitetssykehus

Indikasjoner og resultater etter leverreseksjon ved Rikshospitalet ble for noen år siden presentert for Tidsskriftets lesere (1). I de senere år er mulighetene for kirurgisk fjerning av maligne leversvulster blitt større. Flere svulster eller affeksjon av begge leverlapper behøver ikke lenger bety at pasienten er inoperabel. De aksepterte kriteriene for inoperabilitet er derfor få ved moderne indikasjonsstilling (2). Fjerning av en større del av leveren kan imidlertid representere en utfordring og innebærer oftest reseksjoner utover de standardiserte formelle høyresidige (segment 5, 6, 7 og 8) og venstresidige (segment 2, 3 og 4) reseksjoner (fig 1). Den viktigste begrensende faktor for slike omfattende reseksjoner er volumet av den del av leveren som står igjen etterpå (restlever eller gjenværende lever). Fjernes en for stor del, vil pasienten kunne utvikle leversvikt - som igjen i ytterste konsekvens kan føre til døden. Avgjørende for om leverfunksjonen kan restitueres er om det er tilstrekkelig hypertrofi postoperativt (3).

Ved planlegging av større leverreseksjoner må det derfor tas hensyn til størrelsen på gjenværende del av leveren. Denne kan beregnes volumetrisk ut fra CT-bilder. Hvis restleveren vil være under $25-30 \%$ av den totale, vil pasienten som regel bli bedømt som inoperabel. Om leverparenkymet ikke er normalt, må man planlegge større restlever. Hvis restleveren er for liten til at det kan gjennomføres en trygg leverreseksjon, er det mulig å indusere hypertrofi av den gjenværende lever. Slike store leverreseksjoner kan gjøres som totrinns reseksjonsprosedyrer, som tidligere er omtalt i Tidsskriftet (4). Alternativt kan portvenegrenen til den tumorangrepne delen av leveren emboliseres (portveneembolisering). Ved å vente noen uker vil restleveren hypertrofere, og fjerning av tumorvevet er mulig.

Metoden ble utviklet i 1980-årene av japanske kirurger og først anvendt på en pasient med kolangiokarsinom (5). Vesentlig fordi man var i tvil om metodens sikkerhet var man i den vestlige verden noe nølende med å ta den i bruk. Mange kirurger hadde også et relativt konservativt syn på indikasjoner for leverkirurgi ved maligne sykdommer. Bilobært tumorangrep ble lenge ansett for å være en kontraindikasjon for leverreseksjon, dermed var det ikke aktuelt å gjøre portveneembolisering. Imidlertid har dette endret seg, og metoden regnes nå for å være meget sikker. Dette har ført til utvidede kriterier for leverreseksjon ved både primære og sekundære svulster i leveren. Rikshospitalet tok metoden i bruk i 2002. Her presenterer vi noen av de erfaringer vi har gjort.

\section{Materiale og metode}

I perioden oktober 2002 til desember 2006 ble i alt 18 pasienter som hadde inoperable maligne leversvulster grunnet for liten leverrest akseptert for portveneembolisering. Data er innsamlet retrospektivt som ledd i kvalitetssikring. I samme tidsrom ble det totalt utført 252 leverreseksjoner for maligne lidelser.

Pasientene ble ansett som inoperable hvis forholdet mellom beregnet leverrestvolum

\section{Hovedbudskap}

- Utvalgte pasienter med inoperable maligne leversvulster kan opereres etter portveneembolisering

- Portveneembolisering øker volumet av planlagt restlever

- Ved leverreseksjon kan man oppnå en langtidsoverlevelse tilsvarende den som er observert for primært operable pasienter

- Anvendelse av teknikken forutsetter nøye pasientutvelgelse basert på radiologiske metoder 


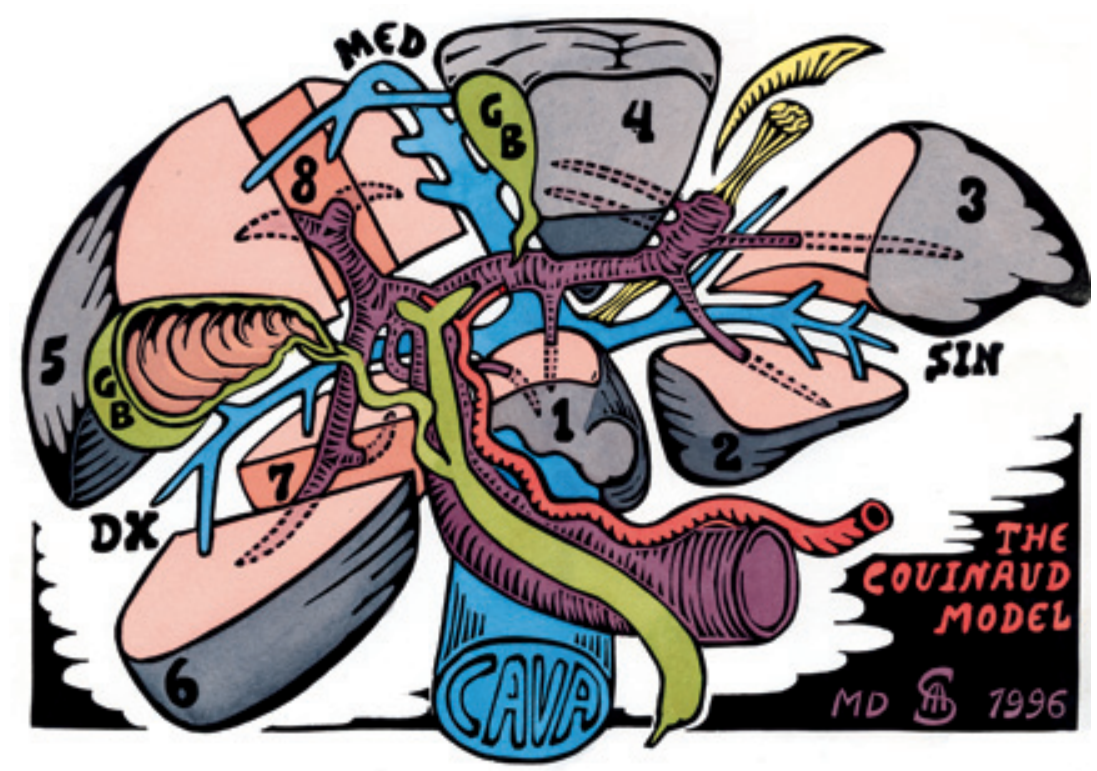

Figur 1 Couinauds segmentinndeling av leveren. Vi ser forgreninger av henholdsvis leverarterier, portvener og galleganger. Forløpet av disse bestemmer grensene for leverens åtte segmenter. Utvidede eller enda større reseksjoner innebærer mer enn formell høyresidig reseksjon omfattende segment 5, 6, 7 og 8 eller formell venstresidig reseksjon omfattende segment 2, 3 og 4 (1). Gjengitt med tillatelse fra Steinar Aasen, Bilde- og intervensjonsklinikken, Rikshospitalet

og det totale levervolum ble estimert til å være mindre enn $0,25-0,30$. Det var ti menn og åtte kvinner med median alder 57 år (35-71 år). De fleste hadde metastaser fra kolorektalcancer $(n=14)$, én hadde metastase fra malignt insulinom i pancreas og tre hadde kolangiokarsinom. Alle hadde sykdom i høyre leverlapp (segment 5, 6, 7 og 8). 11 av dem hadde i tillegg sykdom i segment 4 , to hadde også sykdom i segment 3 og én i segment 1 (fig 1). Pasienter med ekstrahepatisk spredning ble ekskludert, bare pasienter der leverresten var fri for tumor ble inkludert. Før henvisning til Rikshospitalet hadde en pasient fått termisk destruksjon av residivtumor etter tidligere reseksjon. Ved Rikshospitalet fikk to pasienter utført laparoskopisk leverreseksjon som ledd i en totrinnsprosedyre for å gjøre leverresten tumorfri før portveneembolisering.

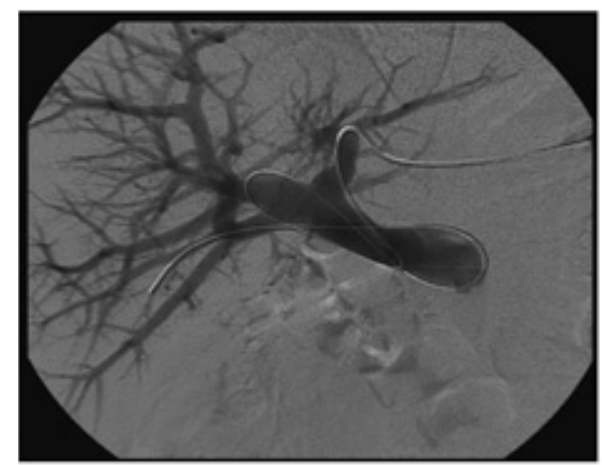

a
Hos alle pasientene ble det utført multidetektor-CT, og volumet av henholdsvis total lever og planlagt leverrest ble estimert. Volumberegningen ble gjort ved summering av arealer målt på aksiale snitt multiplisert med snittykkelsen. Store kar og tumorvev inngikk ikke i leverens totalvolum.

Punksjon av portvenekretsløpet ble utført som intervensjonsradiologisk prosedyre med perkutan transhepatisk tilgang. Hos de fleste ble det gjort innstikk fra venstre side, høyre side ble benyttet hos fire pasienter. En segmentgren av intrahepatisk v. portae ble punktert med finnål under ultralydveiledning. Ved anvendelse av Seldingers teknikk ble en innføringshylse plassert sentralt i portvenen. Ved hjelp av førings- eller mikrokateter ble de enkelte segmentgrenene funnet og embolisert selektivt. Som embolisk agens ble det brukt lim (histakryl og lipiodol), spongostanbiter eller polyvinylpartikler, eventuelt i kombinasjon med coiler (metallspiraler).

Resultatene er angitt som medianverdi med spredning, og ikke-parametrisk metode er brukt for utregning av forskjeller (Wilcoxons test). Overlevelsesdata er angitt som Kaplan-Meier-plott. Statistisk signifikans er angitt til $\mathrm{p}<0,05$.

\section{Resultater}

Antall prosedyrer har økt siden starten i 2002, og i 2006 ble sju pasienter embolisert. I alt 77 pasienter fikk utført leverreseksjon det året. Vellykket portveneembolisering ble initialt observert hos 16 pasienter (fig 2), to trengte ny prosedyre. Disse to var blitt embolisert med coiler og polyvinylpartikler. Begge ble embolisert på nytt med lim. En pasient måtte laparotomeres samme dag grunnet intraabdominal blødning. Aksidentell punksjon av leverarterien ble påvist og suturert. En annen pasient hadde forbigående gallelekkasje etter aksidentell punksjon av gallegang. Denne ble behandlet med endoskopisk anlagt stent $\mathrm{i}$ gallegangen og et perkutant eksternt dren mot subhepatisk beliggende væskeansamling. Tre andre pasienter fikk lette symptomer, som forbigående feber og abdominalsmerter.

To pasienter fikk transaminaseøkning, til over 200 IE/1. Albuminnivået ble signifikant redusert fra median 41,5 g/l til 37,5 g/l ( $\mathrm{p}<$ $0,05)$. Alle laboratorieforandringer var forbigående og normalisert innen få dager. Median liggetid var ett døgn (1-17 døgn).

Ved CT-kontroll median 41 dager (13-67 dager) etter vellykket portveneembolisering var veksten av leverresten median $45 \%$ (9-100\%). Forholdet mellom gjenværende lever og totalt levervolum økte fra median $0,17(0,09-0,31)$ til median $0,25(0,16-0,46)$ etter emboliseringen (fig 3 ).

Tumorprogrediering som utelukket leverreseksjon ble påvist hos fire pasienter ved CT-undersøkelse og ved laparotomi hos tre andre. En pasient kunne ikke behandles grunnet alvorlig bivirkninger etter forsøk på neoadjuvant kjemoterapi. De ti andre fikk utført leverreseksjon. Veksten av leverresten hos disse pasientene var ikke forskjellig fra

Figur 2 al Guidewire og kateter er plassert ved perkutan teknikk i portvenesystemet. b) Begynnende deponering av histakryl/lipiodol i portvenesystemet. c) Ferdig utført portveneembolisering av høyre leverlapps portvenegrener 
veksten hos dem som ikke fikk utført leverreseksjon. Ingen pasienter døde i det umiddelbare postoperative forløpet. Alle hadde preoperativt normalt serum-bilirubinnivå og normal INR-verdi. Postoperativt steg median bilirubin- og INR-verdi til henholdsvis 35 $\mu \mathrm{mol} / 1$ (24-84 $\mu \mathrm{mol} / \mathrm{l})$ og 1,9 (spredning $1,3-2,2)$

Av de ti pasientene som fikk utført leverreseksjon hadde ni metastaser etter kolorektalcancer og én metastaser fra nevroendokrin pancreascancer. To fikk intervensjonstrengende komplikasjoner. Begge hadde gallelekkasje som ble behandlet med endoskopisk innlagt stent i galleveier og perkutant eksternt dren. Mediant tumorantall var fire (1-14 tumorer) og median tumorstørrelse 5 centimeter $(4-11 \mathrm{~cm})$. Fri reseksjonsrand ble påvist hos sju pasienter. Mikroskopisk ikke-fri reseksjonsrand ble påvist hos tre pasienter. Figur 4 viser CT-undersøkelse før og etter portveneembolisering samt etter leverreseksjon.

For dem som ble leverresecert er median observasjonstid 30 måneder (1-65 md.). Av de ni pasientene som ble resecert etter kolorektalcancer er tre døde - etter henholdsvis 11,15 og 36 måneder. To pasienter har fått lungemetastaser og to har fått residiv i leveren, en av disse er behandlet med radiofrekvensablasjon. To er i live uten tegn til residiv etter henholdsvis 47 og 49 måneder. Kaplan-Meier-kurven viser en overlevelse på $58 \%$ etter fire år (fig 5). Bare tre pasienter er observert $i$ under to år. Av de åtte pasientene (inkludert tre med kolangiokarsinom) som ikke ble leverresecert, er bare to i live.

\section{Diskusjon}

Hos alle våre pasienter ble den planlagte leverresten større etter portveneembolisering. To pasienter måtte gjennom to emboliseringer før ønsket resultat ble oppnådd. Dette skyldtes inkomplett embolisering. Det er imidlertid ikke klarlagt om bruk av partikler gir dårligere embolisering enn hvis man bruker $\lim$ (6). Sannsynligvis er det viktig å bruke samme teknikk og samme agens over tid. Vi observerte komplikasjoner hos tre av de 18 pasientene $(17 \%)$, de fleste hadde lette,

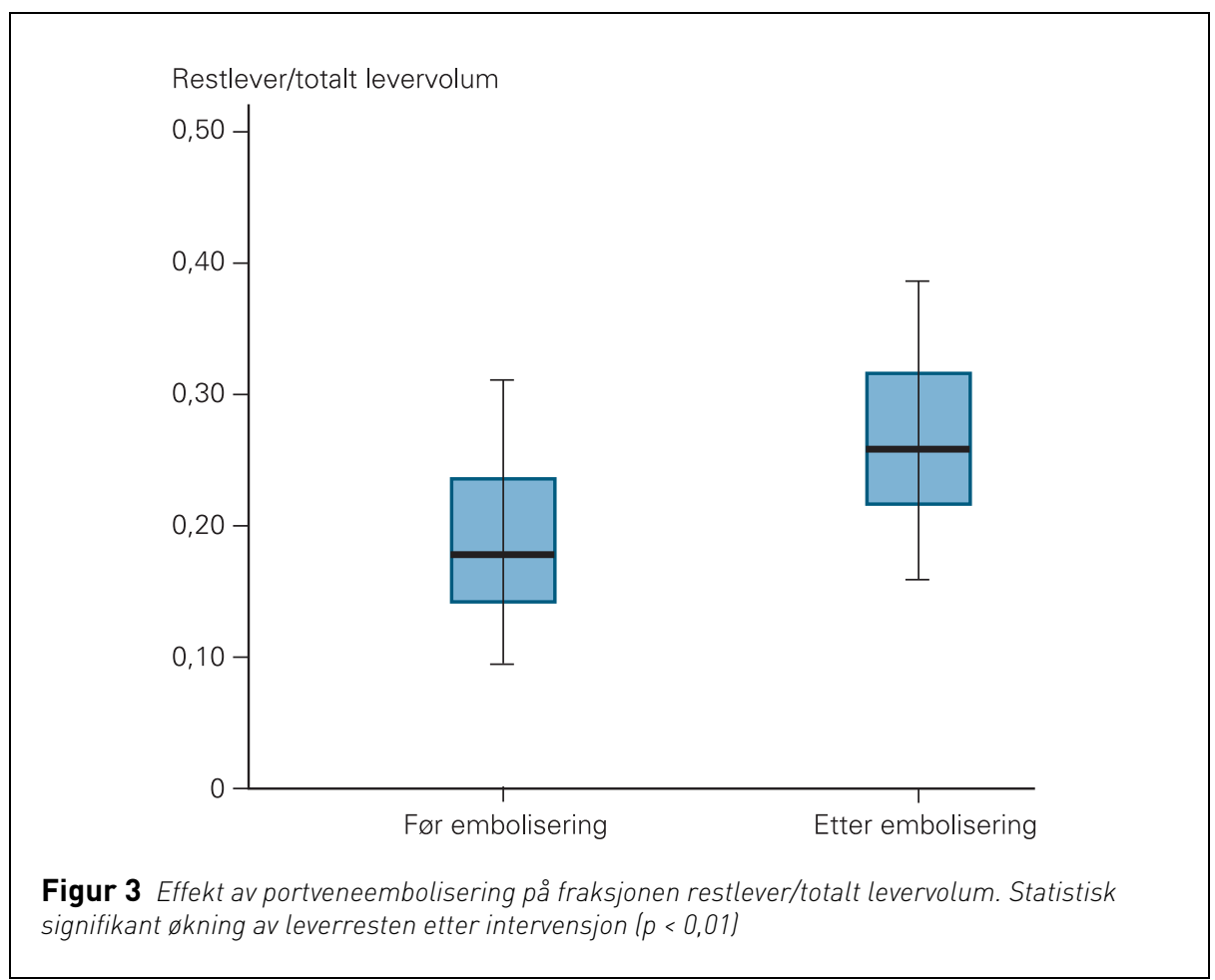

forbigående plager. To av komplikasjonene skyldtes aksidentelle lesjoner ved forsøk på kanylering av en portvenegren. Median liggetid etter portveneembolisering var likevel bare ett døgn.

I høyvolumsentre er portveneembolisering assosiert med tilnærmet ingen morbiditet (7-9). Slik embolisering bør derfor utføres av erfarne intervensjonsradiologer og gjøres ved få sykehus i Norge. Teknikken er med årene blitt mer utbredt og ble brukt ved $9 \%$ av 77 leverreseksjoner i 2006. Sannsynligvis kan flere pasienter her i landet tilbys denne behandlingen.

I spesialiserte sentre er vanlige leverreseksjoner assosiert med svært lav mortalitet $(0-2 \%)$. Mortalitet og morbiditet er direkte relatert til størrelsen av reseksjonen $(10,11)$. Ved utvidede eller enda større leverreseksjoner er volumet og kvaliteten på den planlagte leverresten avgjørende faktorer for utfallet av operasjonen (fig 1). En marginal leverrest kan derfor under slike omstendigheter føre til økt komplikasjonsrate og mortalitet. Metoden kommer derfor i betraktning ved planlegging av slike store leverreseksjoner. Spesielt gjelder dette ved tumoraffeksjon av begge leverlapper. Sannsynligvis bør leverresten ikke være mindre enn $25 \%$ av det totale levervolum (12). Våre data viser en enda lavere median verdi for leverresten. Vi observerte ingen mortalitet, ingen alvorlig postoperativ leversvikt eller sepsis. Ingen av våre pasienter hadde tegn til levercirrhose. Hvis det foreligger parenkymforandringer bedømt histologisk i mer enn 30-50\%, bør leverresten være større.

En del av våre pasienter ble ikke kandidater for leverreseksjon. Dette er forenlig med det andre har funnet $(8,13)$. Alle som ikke ble operert hadde sykdomsprogrediering, utvelgelse av pasienter til portveneembolisering kan følgelig være vanskelig. Vi utreder nå pasientene med multidetektor-CT thorax

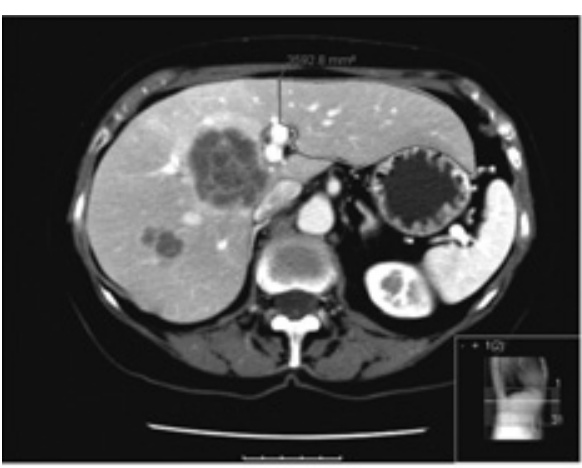

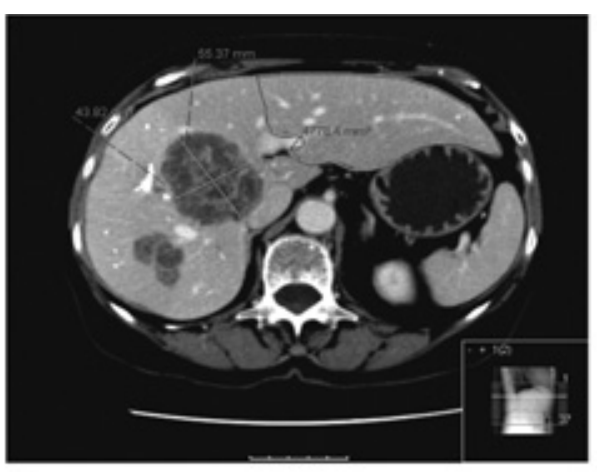

b

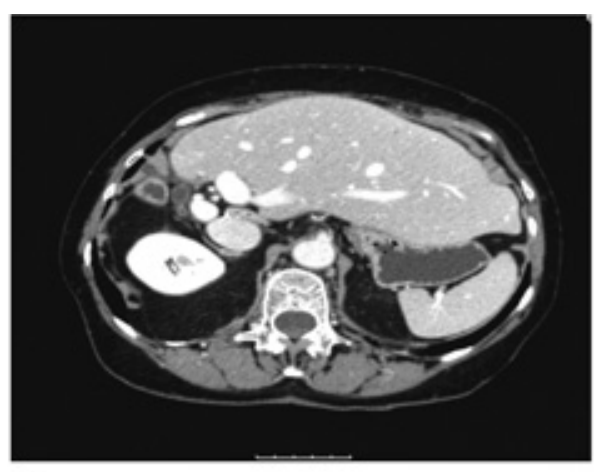

$c$

Figur 4 a) CT lever viser metastasering til lever. Pasienten er tidligere operert for cancer coli. b) Portvenembolisering er utført 40 dager tidligere. Bildene viser hypertrofi av restlever - fraksjonen restlever/totalt levervolum økte fra 0,27 til 0,36. c) Fire år etter utvidet høyresidig leverreseksjon (segmentene 4, 5, 6, 7 og 8 er fjernet) 


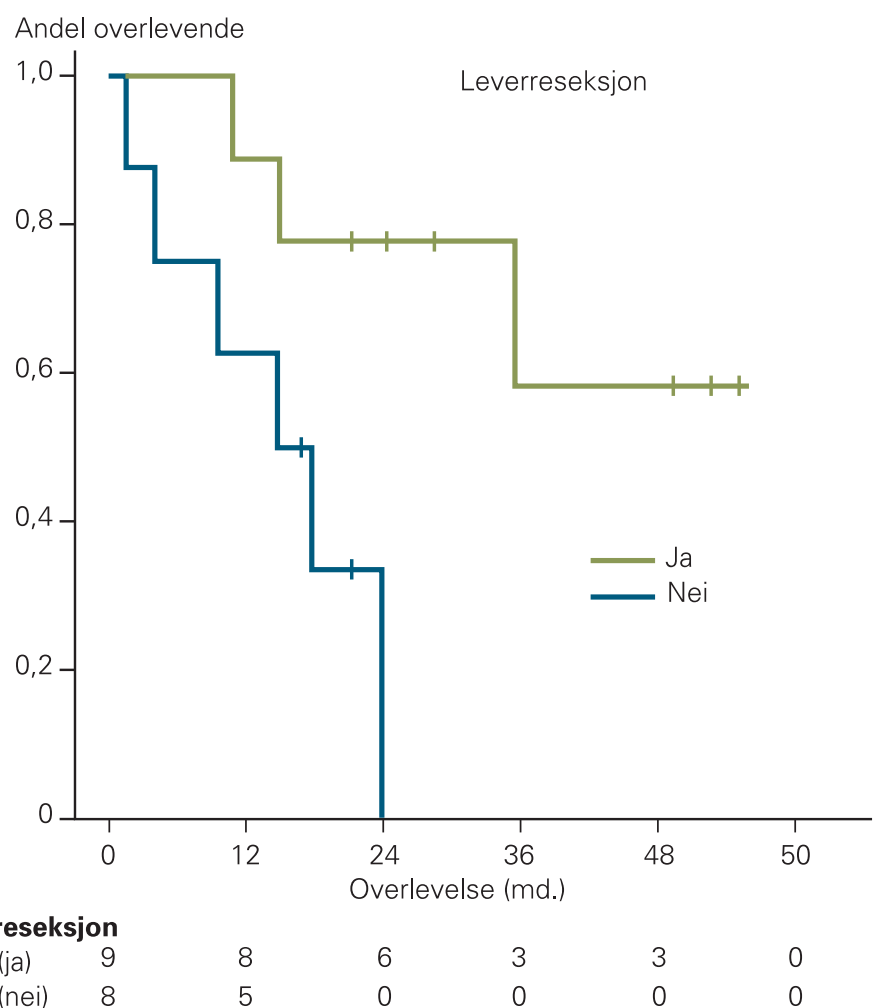

Figur 5 Kaplan-Meier-kurve. Grønn kurve viser overlevelse for ni pasienter primært bedømt som inoperable med metastaser fra kolorektalcancer, leverresecert etter portveneembolisering. Blå kurve viser overlevelse for åtte pasienter som etter portveneembolisering ikke ble leverresecert

og abdomen samt med positronemisjonstomografi (PET). PET-undersøkelse var ikke tilgjengelig hos oss da vi startet med denne behandlingen.

Pasienter med ekstrahepatisk vekst kan vurderes for behandling. Det er mulig å fjerne metastaser fra både lever og lunger med godt resultat (14). Langtidsoverlevelsen er avhengig av om man kan fjerne metastaseringen radikalt. For pasientene med kolorektale levermetastaser som ble operert etter portveneembolisering er overlevelsen sammenliknbar med det som kan oppnås hos primært operable pasienter (fig 5). Innvendingen er selvfølgelig at vårt materiale er lite. Det er viktig å ha klart for seg at alle
Litteratur

1. Mala T, Bergan A, Edwin B et al. Leverreseksjon indikasjoner og resultater. Tidsskr Nor Lægeforen 2001: 121: 2476-80.

2. Van Cutsem E, Nordlinger B, Adam R et al. Towards a pan-European consensus on the treatment of patients with colorectal liver metastases. Eur J Cancer 2006; 42: 2212-21.

3. Yokoyama $Y$, Nagino M, Nimura Y. Mechanisms of hepatic regeneration following portal vein embolization and partial hepatectomy: a review. World J Surg 2007; 31: 367-74.

4. Nermoen I, Foss A, Holte $\mathrm{H}$ et al. Kirurgisk behandling av hormonproduserende binyrebarkkarsinom med levermetastaser. Tidsskr Nor Lægeforen 2004; 124: 3061-3.

5. Makuuchi M, Thai BL, Takayasu K et al. Preoperative portal embolization to increase safety of major hepatectomy for hilar bile duct carcinoma: a preliminary report. Surgery 1990; 107: 521-7.

6. Madoff DC, Hicks ME, Abdalla E et al. Portal vein embolization with polyvinyl alcohol particles and coils in preparation for major liver resection for hepatobiliary malignancy - study in 26 patients. Radiology 2003; 227: 251-60.

7. Ribero D, Abdulla EK, Madoff DC et al. Portal vein embolization before major hepatectomy and its effects on regeneration, resectability and outcome. Br J Surg 2007; 94: 1386-94.

8. Elias D, Ouellet J-F, de Baere T et al. Preoperative selective portal vein embolization before hepatectomy for liver metastases: long-term results and impact on survival. Surgery 2002; 131: 294-9.

9. Nagino M, Kamiya J, Nishio H et al. Two hundred forty consecutive portal vein embolizations before extended hepatectomy for biliary cancer. Ann Surg 2006; 243: $364-72$

10. Belghiti J, Hiramatsu K, Benoist S et al. Seven hundred forty-seven hepatecomies in the 1990s: an update to evaluate actual risk of liver resection. J Am Coll Surg 2000; 191: 38-46.

11. Melendez J, Ferri E, Zwillman M et al. Extended hepatic resection: a 6-year retrospective study of risk factors for perioperative mortality. J Am Coll Surg 2001; 192: 47-53.

12. Ferrero A, Vigano L, Polastri R et al. Postoperative liver dysfunction and future remnant liver: where is the limit? World J Surg 2007; 31: 1643-51.

13. Abdalla EK, Barnett CC, Dohery D et al. Extended hepatectomy in patients with hepatobiliary malignancies with and without preoperative portal vein embolization. Arch Surg 2002; 137: 675-81.

14. Pfannschmidt J, Dienemann H, Hoffmann H. Surgical resection of pulmonary metastases from colorectal cancer: a systemic review of published series. Ann Thorac Surg 2007; 84: 324-38.

Manuskriptet ble mottatt 1.2. 2008 og godkjent 9.9. 2008. Medisinsk redaktør Kjetil Søreide. 